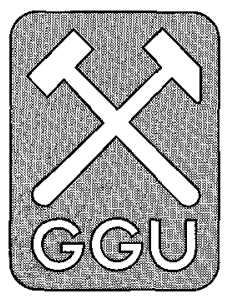

\title{
Discovery of live oil at Marraat, Nuussuaq: field work, drilling and logging
}

\author{
Flemming G. Christiansen, Gregers Dam \\ and Asger K. Pedersen
}

Observations of oil seepage and bitumen impregnation at the surface are very important in an early evaluation of the exploration potential of a sedimentary basin, since they usually demonstrate the existence of an oil-prone source rock and that oil generation has taken place somewhere in the subsurface. Such evidence has been reported from most onshore sedimentary basins in Greenland, and solid bitumens have in many cases been correlated to a known source rock in the immediate vicinity, or in rare cases interpreted as long-distance migration from a known or an inferred source rock (see review by Christiansen, 1994).

In West Greenland previously described evidence of hydrocarbon generation has been restricted to two examples of highly coalified solid bitumens, one on the island of Qeqertarsuaq to the north of Uummannaq (Henderson, 1969) and one at Marraat Killiit on Nuussuaq (Pedersen, 1986). Additional evidence of hydrocarbon generation (but as gas), observed as bubbles in fountains or lakes in pingos in the Aaffarsuaq valley on Nuussuaq, was mentioned by Henderson (1969) and Henderson et al. (1976), who also quoted old local rumours of seepage.

The 1990-1992 expeditions to the onshore part of the Cretaceous-Tertiary sedimentary basin in the DiskoNuussuaq-Svartenhuk Halvø region of West Greenland were focused on stratigraphical, sedimentological and organic geochemical studies of the sediments in order to assess the hydrocarbon potential of the area (Christiansen, 1993). In addition one team studied the development of the Tertiary volcanics and their interaction with the sediments. Both those teams working on the sediments and those studying the volcanics devoted some time to the search for seeps or impregnations of bitumen.

One significant oil-impregnation was found in the lowermost part of the Tertiary volcanics on the south-west coast of Nuussuaq near Marraat at the end of the 1992 field season (Christiansen, 1993). This discovery was not a surprise, since it was located only a few kilometres from a previously described locality with highly coalified bitumen. However, it was very encouraging that analysis by extraction, gas chromatography and mass spectrometry showed that the oil had only suffered minor biodegradation and no thermal alteration. Furthermore, the presence of the bio- marker compound oleanane suggested that the source rock was Tertiary (or latest Cretaceous) in age and was deposited in a marine environment dominated by terrestrially derived organic matter, e.g. a deltaic succession or prodeltaic muds.

The implications of these organic geochemical data are very important: for the first time the existence of an oilprone source rock is demonstrated in West Greenland which exploration-wise has suffered from the 'gas-prone' reputation based on experience from the activities in the 1970s offshore Labrador and West Greenland. Based on these encouraging results it was decided to carry out additional field work in 1993 in order to study the extent of the oil-impregnation, and also to examine several localities on Hareøen which are situated in a similar tectonic setting near the Itilli fault zone (Fig. 1). Furthermore it was planned to drill close to the discovery locality if appropriate equipment became available.

\section{3 field work}

\section{Hareфen}

Reconnaissance on Hareøen concentrated on the southern and eastern parts of the island, where a major fault zone separates the Vaigat Formation (towards the southeast) from the Maligat and Hareøen Formations, with a possible vertical component of displacement of several kilometres (Fig. 1). No relics of hydrocarbons were recorded in the basalts on either side of the less than $25 \mathrm{~m}$ wide fault zone, which is a possible continuation of a major strike-slip fault of the Itilli fault zone. In general the porosity of the basalts on both sides of the fault in this area appears very low, and most vugs and fractures are filled with calcite and occasionally aragonite, quartz or zeolites.

Samples for organic geochemical and palynological analysis were collected from a number of sedimentary units on Hareøen. These include poorly exposed intrabasaltic sediments (from less than $10 \mathrm{~m}$ to about $40 \mathrm{~m}$ thick), and an up to $6 \mathrm{~m}$ thick succession of resiniterich coals and shales considered to be the youngest preQuaternary deposits in the Disko-Nuussuaq-Hareøen region. 


\section{Marraat}

The main goals of the field work in the Marraat area were to trace the zone of oil impregnation laterally and to select a suitable drilling location.

The Marraat area was mapped and studied in detail in 1971 and 1972 by Gilroy Henderson (GGU unpublished map 1:10 000). Some results were published by Henderson (1975) and compiled onto the GGU 1:100 000 map 70 V.1N (Agatdal sheet). As background for the present study a preliminary exposure map on the scale 1:2000 covering the oil-seep and the drill-site was prepared with the aid of multi-model photogrammetry (Dueholm \& Pedersen, 1992).

The main oil-impregnation is found in vesicular flow tops within a series of subaerial basaltic lava flows mapped by Henderson (1975) as 'fine-grained aphyric basalts'. The lavas belong to the oldest part of the Vaigat Formation, a level deeper than that found on Disko and covered by the detailed lithostratigraphy of Pedersen (1985). They probably had a former cover of several kilometres of younger volcanic rocks.

The aphyric basalts can be mapped out as a light brownishweathering marker horizon and help to define the structure of the area. These are underlain by subaerial picrite lavas and more olivine-poor basalts, and by two units of hyaloclastite. From the outcrop pattern along the coast north of the first oil-discovery locality, the hyaloclastites are inferred to have a thickness exceeding $300 \mathrm{~m}$. Minor oilimpregnation has affected the uppermost hyaloclastite.

The extent of oil-impregnation as presently known in surface exposures is indicated on Figure 1. Many individual thin zones have been traced for distances of $20 \mathrm{~m}$ to more than $100 \mathrm{~m}$. The two main areas of oil-impregnation are in two different fault blocks $1.5 \mathrm{~km}$ apart, but in both cases hosted by the same marker flows. At the oil-discovery locality, the breccias are inferred to have a thickness of at least $300 \mathrm{~m}$, and probably not more than $600 \mathrm{~m}$. The boundary to the underlying sediments is only observed as a fault exposed along the coast but the general pattern in the terrain may be deduced from minor outcrops in the poorly exposed terrain east of the Itilli valley.

Structurally the Marraat area is rather complex being situated at the eastern margin of a major fracture zone system - the Itilli fault zone, which is situated in the Itilli valley about $5 \mathrm{~km}$ to the north. The margin of the fault zone displays compressional features and a large number of dykes (up to 5-10\% of the total rock volume) which represent several phases of dyke emplacement. Due to the heating effects of local dykes and sills and especially a number of hydrothermal fields marked by an abundance of mineralised veins (Binzer \& Karup-Møller,1974; Karup-Møller, 1969), and possibly also deeper subsidence and higher uplift than other areas on Nuussuaq, the thermal maturity of the sediments in the Itilli valley is high with vitrinite reflectance values between $2 \%$ and $3.5 \%$.

However, just a few kilometres east of the Itilli valley, the uppermost part of the exposed sediments found just beneath Tertiary hyaloclastites, has a much lower thermal maturity (TAI: $2^{+}-3$ ) and palynomorphs may be recognised and identified (Nøhr-Hansen, 1993).

In the Marraat area the volcanics dip $15^{\circ}-25^{\circ}$ towards the east and the succession is cut by a number of $\mathrm{N}-\mathrm{S}$ and NNW-SSE trending, steeply dipping faults with a westerly downthrow (Henderson, 1975, fig. 3; Fig. 1). Several kilometres farther to the north, north-east and east, the dips of the flow are lower $\left(\sim 5^{\circ}\right.$ to the $\mathrm{E}$ and $\left.\mathrm{SE}\right)$, and in central Nuussuaq the flows are close to horizontal and the number of faults is much smaller.

\section{Drilling of the Marraat-1 well}

The main aims of the Marraat-1 well were to evaluate the number and thickness of the oil-impregnated zones, their geological control, as well as 'reservoir', petrophysi$\mathrm{cal}$ and geochemical properties. Furthermore it was aimed to penetrate the lowermost part of the volcanic succession in order to reach the underlying sedimentary units. The sediments are assumed to include oil-prone potential source rocks, and possibly also intercalated oil-impregnated sandstones comparable to the Itilli succession described by Dam \& Sønderholm (in press).

In addition it was hoped to obtain information on the stratigraphy and lithology of the volcanic and sedimentary rocks in order to integrate data in future seismic or other geophysical surveys. It was also considered important to measure the down-hole temperature distribution, especially for evaluation of the possibility of permafrost as a secondary seal for oil and gas, for technical purposes and to measure the geothermal gradient and heat flow for basin modelling studies.

The drilling of the Marraat-1 well took place in the period 15-21 August and was undertaken by Petro Drilling Company Limited, Canada with a wire-line diamond drilling outfit. All technical data from the drilling programme are presented in detail in the well completion report by Dam \& Christiansen (1994).

A total of $446.85 \mathrm{~m}$ of core with a recovery close to $100 \%$ was sampled, described and subsequently shipped back to Copenhagen. Due to technical problems it was not possible to reach the sediments underlying the volcanics. The core piece at termination depth represents the oldest known Tertiary volcanic rock onshore West Greenland. The core confirmed the results from the fieldwork, namely that a series of porous zones in the lavas down to a depth of $86 \mathrm{~m}$ contain liquid oil (Fig. 2). These lavas overlie a succession of lava flows, pillow lavas and hyaloclastites 

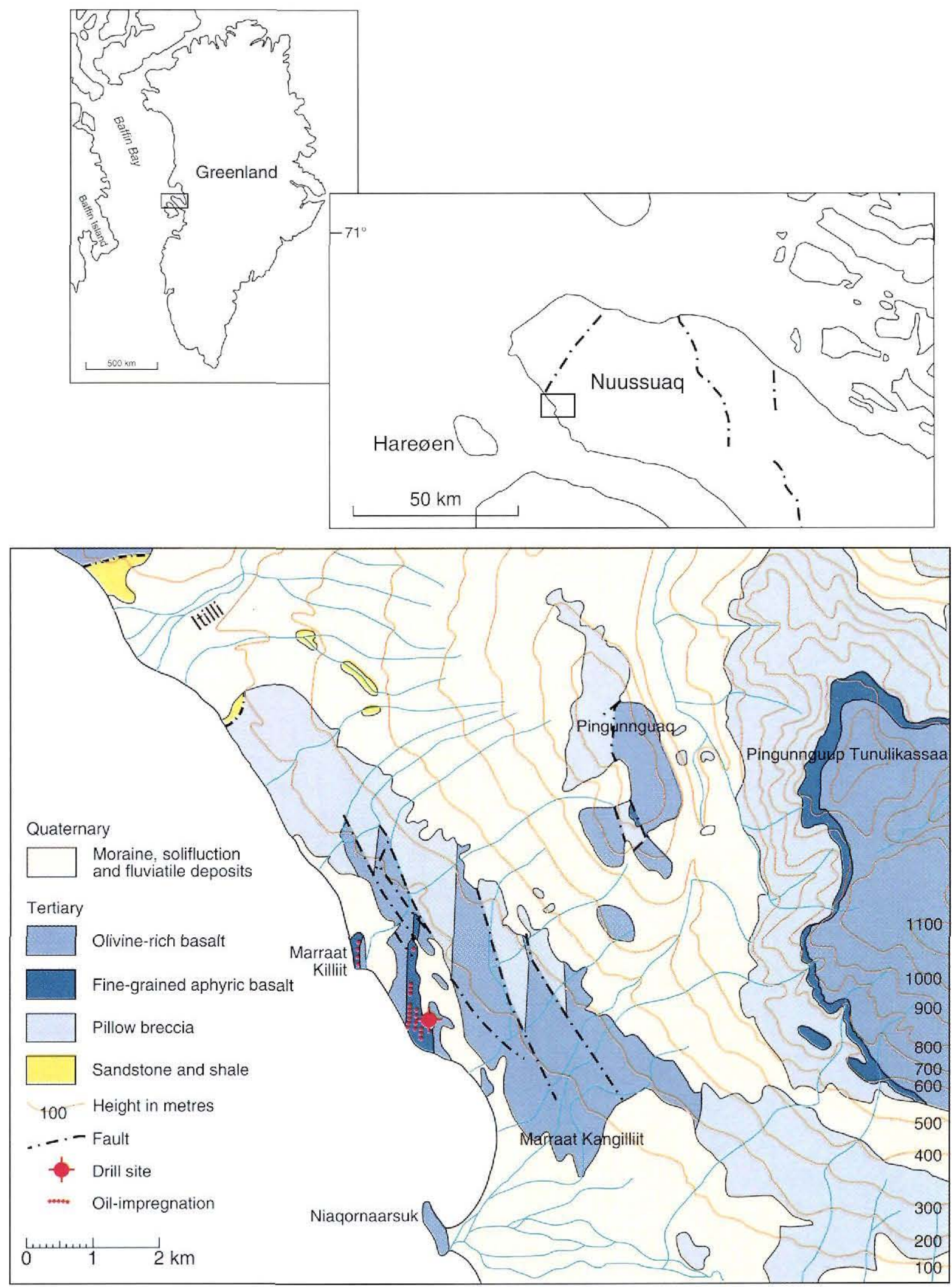

Fig. 1. Map of the Marraat area based on Henderson (1975). 


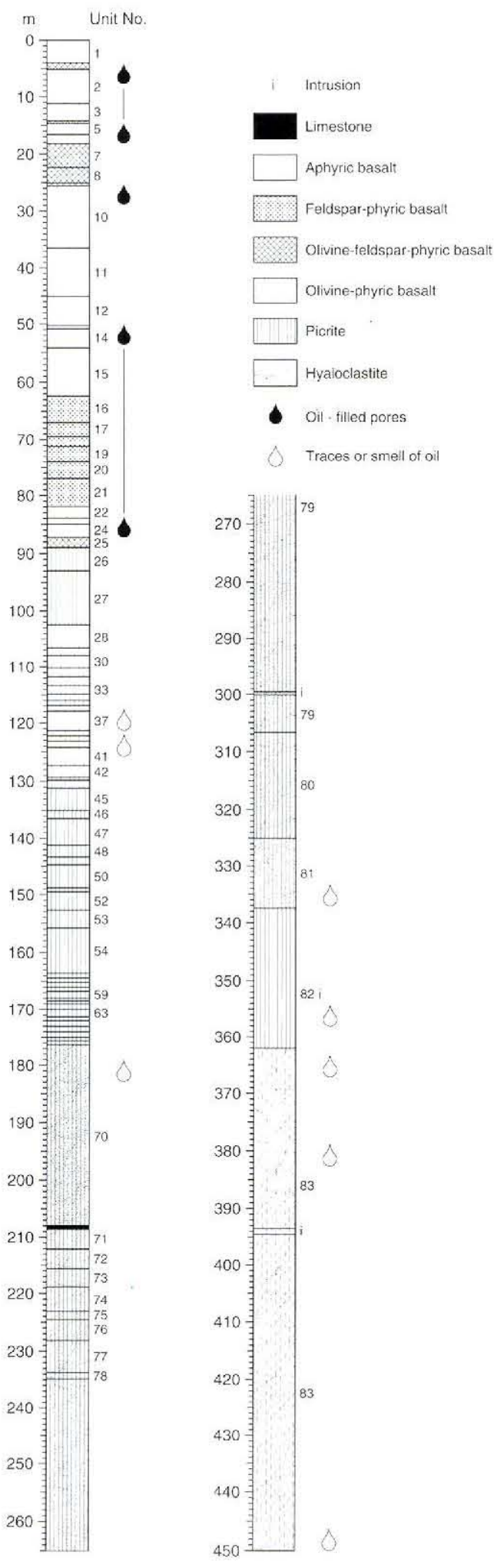

Fig. 2. Log of the Marraat-1 well, based on unpublished data by L. M. Larsen and A. K. Pedersen. with poor porosity and permeability and with only few traces of oil.

After completion of drilling and moving of equipment it became evident that formation water and flammable gas was liberated from the hole and a valve was mounted on the top of the casing. A thermistor string was lowered into the water-filled hole in order to measure the temperature variation and the thickness of the permafrost in the area.

\section{Logging, VSP, sampling of formation fluids and other drill site measurements in the Marraat-1 well}

After the drilling of the Marraat-1 well was successfully completed, and the first promising geochemical results, it was decided to carry out a geophysical programme in the well, including a geophysical logging programme, sampling of formation fluids and a vertical seismic profile (VSP). The programme was designed and undertaken by Rambøll, Hannemann \& Højlund A/S, Denmark, assisted by personnel from GGU. The suite of geophysical logs included natural gamma ray, gamma-gamma, neutron-neutron (porosity), guard resistivity, spontaneous potential, single point resistance, temperature, caliper and deviation.

The programme was carried out between late October and early November 1993 (Fig. 3). All technical data from the geophysical logging. VSP, pumping and test programme are presented in detail in the well completion report by Dam \& Christiansen (1994).

After completion of the drilling programme, an ice-plug had developed in the uppermost $17 \mathrm{~m}$ of the water-filled hole. The ice was removed using a hot water jet drill (Olesen \& Clausen, 1988). During the following geophysical logging programme the hole was kept ice-free by adding salt and inserting an electric heat cable into the hole. The caliper log demonstrates an even-sized hole with only few caves or 'breakouts'. However, there is a major obstruction at a depth of $-350 \mathrm{~m}$ which the logging tools were not able to pass. The vertical seismic profile (VSP) was carried out with a hydrophone cable with 12 hydrophones $2 \mathrm{~m}$ apart. Following the geophysical logging programme 24 formation fluid samples were taken at 8 levels in the upper $86 \mathrm{~m}$ of the well.

In order to obtain key data for planning future geophysical and drilling programmes, a number of tests were carried out in addition to the borehole measurements. A seismic Walkaway Noise Test (WNT) and several geomagnetic lines were acquired in the drill site area, and four echo-sounding lines were recorded in the nearshore areas.

Fig. 3. The Marraat-1 drill-site on the south coast of Nuussuaq during drilling in mid-August 1993 (upper) and logging in late October 1993 (lower). 

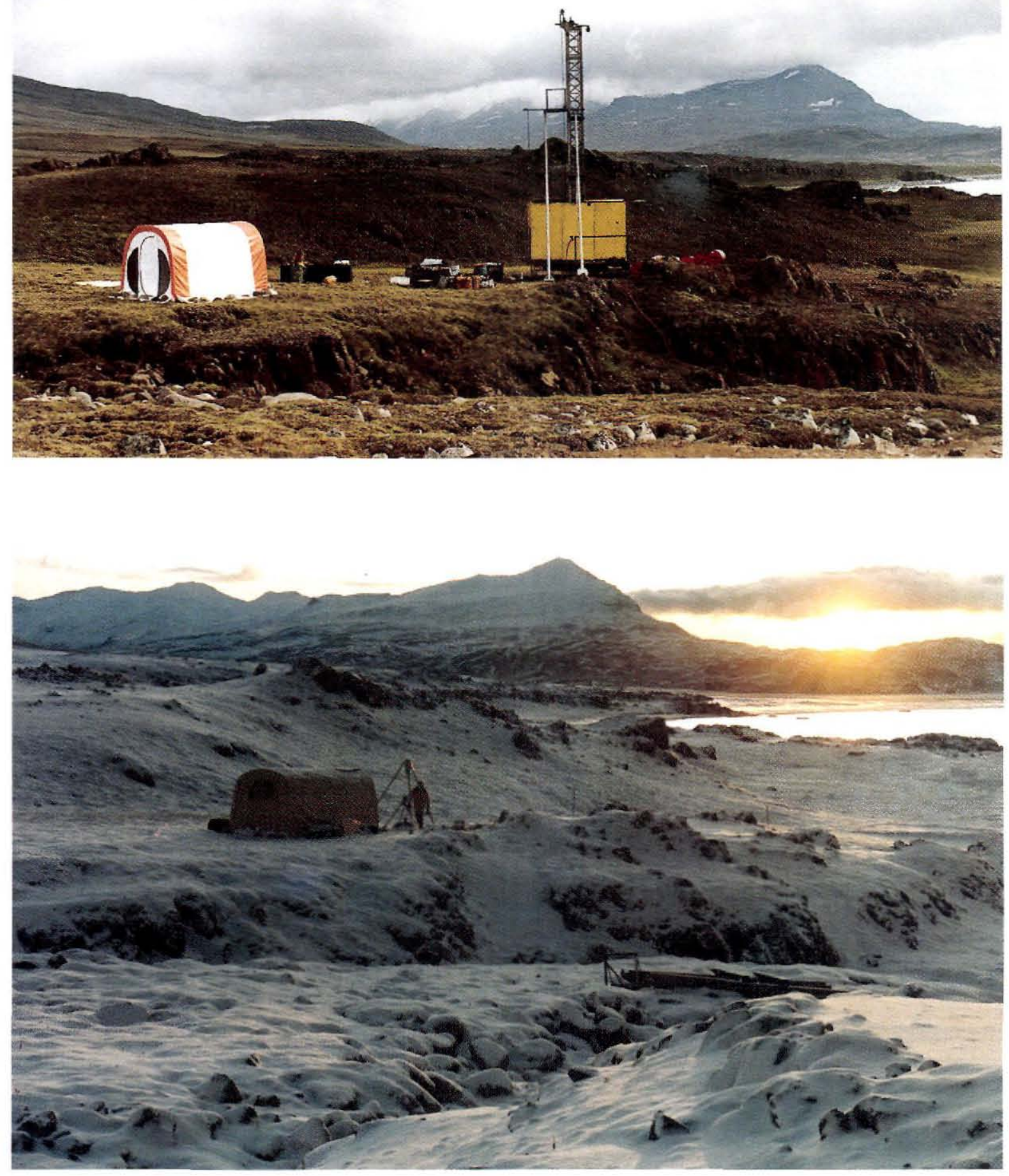


\section{Analytical programme}

A major analytical programme was carried out on surface samples and cores from the Marraat- 1 well, and more detailed work is under way. This work focuses on organic geochemistry (pyrolysis, extraction, gas chromatography (GC), mass-spectrometry (GCMS), carbon-isotopes, petrography, petrology and petrophysical properties of the basalts, geochemistry of water and gas (chromatography, isotope composition of methane) from the drill hole and various other localities.

The organic geochemical data are presented in detail elsewhere (Christiansen et al., 1994a, b, c); the main conclusions can be summarised as follows:

(1) Surface samples from both fault blocks and the well show more or less constant geochemical patterns (GC and GCMS). There is a minor variation in biodegradation, whereas the parameters controlled by thermal maturity or the depositional environment of the source rock are remarkably constant.

(2) The pattern of variation in biodegradation and surface evaporation suggests active replenishment.

(3) The thermal maturity of the generating source rock is relatively low, corresponding to the upper part of the 'oil window'. By comparison, similar maturity is recorded at depths of $c .3400 \mathrm{~m}$ in the Ikermiut-1 well, offshore Central West Greenland.

(4) The geochemical data indicate that the oil-prone organic material in the source rock is mainly terrestrial in origin but deposited in a marine environment. This points towards deltaic or prodeltaic mudstones as the source rock, probably of latest Cretaceous or Early Tertiary age.

\section{Implications for future activities}

The implications of the Marraat discovery are very encouraging for future exploration offshore West and NorthWest Greenland since it demonstrates for the first time that an oil-prone source rock exists in the region and thus challenges the 1970s conclusion of the area as being entirely gas-prone.

The ongoing analytical work is likely to provide additional details on the degradation history of the oil, on the gas and formation fluids associated with the oil, on the depositional environment and thermal history of the source rock, and on the amount of oil that was once in place in the recognised structures in the Marraat area. However, a number of important questions still remain unanswered:

- Is there a source rock or oil accumulation in the sediments underlying the volcanics, or does the oil originate directly from long-distance migration?
- What is the thickness, distribution, and generative potential of the source rock?

- What is the stratigraphy and structure of the sediments underlying Marraat; are there any trapping configurations?

- Is there a local oil exploration potential on Nuussuaq?

To resolve these questions, a number of different activities are likely to take place in the Marraat area and surrounding region in the future, primarily aiming at deeper drilling. In order to minimize the drilling risk additional field work (structural analysis of the volcanic and sedimentary succession, search for additional information on oil and gas seepage, volcanic stratigraphy and palaeomagnetism, studies of hydrothermal alteration) and various onshore geophysical studies are necessary. Furthermore it is important to carry out both shallow geophysical surveys and conventional seismic surveys in the near-shore areas in order to extrapolate the results to the major offshore areas of West and North-West Greenland.

Acknowledgements. The Mineral Administration for Greenland funded the drilling and logging programme. Arktisk Station at Qeqertarsuaq/Godhavn made the ship Porsild available for the field work. The drilling programme was completed in collaboration with three Canadian companies: Falconbridge Ltd, Universal Helicopters and Petro Drilling Company Ltd. In particular, thanks are due to Falconbridge's project leader Kevin Olshefsky and to Carsten Ploug from Rambøll, Hannemann \& Højlund A/S for good planning. Morten Dam, Finn Steffens and the crew onboard Maja $S$ and Puttut are thanked for practical support under severe weather conditions during completion of the logging programme.

\section{References}

Binzer, K. \& Karup-Møller, S. 1974: Ferri-sepiolite in hydrothermal calcite-quartz-chalcedony veins on Nûgssuaq in West Greenland. Bull. Grønlands geol. Unders. 114, 16 pp.

Christiansen, F. G. 1993: Disko Bugt Project 1992, West Greenland. Rapp. Gronlands geol. Unders. 159, 47-52.

Christiansen, F. G. 1994: Seeps and other bitumen showings: a review of origin, nomenclature and occurrences in Greenland. Open File Ser. Grønlands geol. Unders. 94/7, 21 pp.

Christiansen, F. G., Bojesen-Koefoed, J., Dam, G., Nytoft, P. \& Pedersen, A. K. 1994a: Oil discovery onshore West Greenland: characterization of thermal history and depositional environment of an as yet untouched source rock. Exploration Update '94, Calgary, May 10-12, 1994. Program with abstracts.

Christiansen, F. G., Bojesen-Koefoed, J., Dam, G. \& Pedersen, A. K. 1994b: Live oil onshore West Greenland: a new and encouraging discovery. AAPG Annual Meeting, Denver, June 1215, 1994. Program with abstracts.

Christiansen, F. G., Bojesen-Koefoed, J. \& Nytoft, H. P. 1994c: Organic geochemistry of oil-impregneted cores form the Marraat-1 well, Nuussuaq, West Greenland - comparison with sur- 
face samples. Open File Ser. Grønlands geol. Unders. 94/8, $26 \mathrm{pp}$.

Dam, G. \& Sønderholm, M. in press: Lowstand slope channels of the Itilli succession (Maastrichtian-Lower Paleocene), Nuussuaq, West Greenland. Sed. Geol.

Dam, G. \& Christiansen, F. G. 1994: Well summary, Marraat-1, Nuussuaq, West Greenland. Open File Ser. Grønlands geol. Unders. 94/11, 27 pp.,

Dueholm, K. S. \& Pedersen, A. K. (ed.) 1992: Geological analysis and mapping using multi-model photogrammetry. Rapp. Gronlands geol. Unders. 156, 72 pp.

Henderson, G. 1969: Oil and gas prospects in the CretaceousTertiary sedimentary basin of West Greenland. Rapp. Gronlands geol. Unders. 22, $63 \mathrm{pp}$.

Henderson, G. 1975: Stratigraphy and structure of the Tertiary volcanic rocks of the Marrait kitdlît area, Nûgssuaq. Rapp. Gronlands geol. Unders. 69, 11-16.

Henderson, G., Rosenkrantz, A. \& Schiener, E. J. 1976: Cretaceous-Tertiary sedimentary rocks of West Greenland. In Escher, A. \& Watt, W. S. (ed.) Geology of Greenland, 341-362. Copenhagen: Geol. Surv. Greenland.
Karup-Møller, S. 1969: Xonotlite-, pectorite-, and natrolite-bearing fracture veins in volcanic rocks from Nûgssuaq, West Greenland. Bull. Grønlands geol. Unders. 80 (also Meddr Grønland 186,2) $19 \mathrm{pp}$.

Nøhr-Hansen, H. 1993: Upper Maastrichtian? - lower Paleocene dinoflagellate cysts and pollen from turbidites in the Itilli region, Nuussuaq, central West Greenland - first dating of sediments. Rapp. Grønlands geol. Unders. 159, 81-87.

Olesen, O. B. \& Clausen, A. 1988: Test drilling with hot water jet at the Inland Ice margin, Pâkitsup, central West Greenland. Rapp. Gronlands geol. Unders. 140, 121-124.

Pedersen, A. K. 1985: Lithostratigraphy of the Tertiary Vaigat Formation on Disko, central West Greenland. Rapp. Gronlands geol. Unders. 148, 65-73.

Pedersen, A. K. 1986: Indication of migrated hydrocarbons in Tertiary volcanics rocks from western Nûgssuaq, central West Greenland. Rapp. Grønlands geol. Unders. 130, 32-35.

F. G. C. \& G. D., Geological Survey of Greenland, Copenhagen. A. K. P., Geological Museum, Øster Voldgade 5-7, 1350 Copenhagen $K$. 